\title{
Učinak proteina iz uljne pogače lana na rast i produktivnost CHO-E i HEK-293T stanica
}

\author{
Effect of flaxseed oil cake proteins on CHO-E and HEK-293T \\ cells growth and productivity
}

\author{
Marijan Logarušić, Igor Slivac*, Kristina Radošević, Višnja Gaurina Srček
}

${ }^{1}$ Laboratorij za tehnologiju i primjenu stanica i biotransformacije, Prehrambeno-biotehnološki fakultet, Sveučilište u Zagrebu, Pierottijeva 6, 10000 Zagreb, Croatia

*Correspondingauthor: islivac@pbf.hr

\begin{abstract}
Sažetak
Nastojanje suvremene prehrambene industrije je što učinkovitije iskoristiti organske ostatke nastale preradom sirovina u prodajne proizvode. Primjer takvog organskog ostatka je i uljna pogača, koja zaostaje nakon ekstrakcije ulja iz sjemenki lana, a zbog svog sastava proteina predstavlja potencijalnu sirovinu za primjenu u tehnologiji uzgoja stanica. Stoga je iz uljne pogače lana izoliran proteinski izolat te je ispitan njegov utjecaj na rast CHO-E i HEK-293T staničnih linija, kao i na produktivnost CHO-E stanične linije. Dokazano je da dodatak proteinskog izolata u hranjivi medij u vrlo niskim koncentracijama (0,1 $g L^{-1}$ i/ili $\left.0,2 g L^{-1}\right)$ ima pozitivan učinak na rast obje stanične linije, kao i na produktivnost CHO-E stanične linije. Međutim, dodatak većih koncentracija izolata od navedenih ne utječe pozitivno na rast obje stanične linije, odnosno na njih djeluje inhibitorno.
\end{abstract}

Ključne riječi: uljna pogača lana, proteinski izolat, rekombinantni protein, kulture stanica

\begin{abstract}
Many industries are looking for efficient exploitation of organic residues from various domain of agriculture and food manufacturing. An example of such organic residue is the oil cake, which remains after extraction of oil from flaxseeds, and due to its protein composition, is a potential raw material for use in cell culture technology. Therefore, after the isolation of a protein isolate from flaxseed oil cake, its effect on the growth and productivity of the CHO-E cell line as well as on the growth of the unproductive HEK-293T cell line was examined. Addition of protein isolate to the nutrient medium at very low concentrations $(0.1$ $g L^{-1}$ and / or $\left.0.2 \mathrm{~g} \mathrm{~L}^{-1}\right)$ has been shown to have a positive effect on the growth of both cell lines as well as on the productivity of the CHO-E cell line. However, the addition of isolates at concentrations higher than above mentioned exhibits cell growth inhibition.
\end{abstract}

Keywords: flaxseed oil cake, protein isolate, recombinant protein, cell cultures

\section{Uvod}

Za uspješan rast, proliferaciju i produktivnost kulture stanica u in vitro uvjetima nužno je osigurati optimalne uvjete mikrookoliša. Uz parametre poput odgovarajuće temperature, $\mathrm{pH}$ i sastava zraka, stanicama je potreban i odgovarajući hranjivi medij. Stoga medij za uzgoj sadržava hranjive tvari poput ugljikohidrata, soli, lipida, aminokiselina, vitamina te hormona (Moraes i sur. 2008). Kako bi se postigli što povoljniji uvjeti za rast stanica uobičajeno je da se u hranjivi medij dodaje i serum životinjskog podrijetla (5-20\%) koji predstavlja izvor dodatnih nutrijenata kao i važnih regulatornih faktora i faktora rasta (Babcock i sur. 2010). Međutim, posljednjih 30-ak godina nastoji se izbjegavati dodavanje seruma u medij za uzgoj zbog nekih negativnih strana njegove primjene. Serum ima nedovoljno definirani sastav, potencijalni je izvor bioloških kontaminanata (gljivice, virusi, prioni), a njegovo korištenje otežava pročišćavanja konačnog proizvoda. Stoga znanstvenici pokušavaju pronaći odgovarajuće zamjene za serum (Chabanon i sur. 2008).

Propisani regulatorni zahtjevi zabranjuju korištenje komponenti životinjskog podrijetla u biotehnološkim proizvodnim procesima s kulturama stanica, pa se kao najbolja alternativa serumu sve više ističe primjena proteina i peptida biljnog podrijetla (Farges-Haddani i sur. 2006). Uljne pogače, koje zaostaju nakon ekstrakcije ulja sjemenki, a sadrže značajne koncentracije proteina i biološki aktivnih spojeva, imaju veliku mogućnost primjene kao zamjena za serum ili dodatak hranjivom mediju u tehnologiji životinjskih stanica. Takve uljne pogače uglavnom su se do sada koristile kao stočna hrana ili gnojivo ili su iz njih izolirani proizvodi s dodanom vrijednošću kao što su enzimi, antibiotici, biopesticidi, vitamini i biološki aktivni metaboliti (Ramachandran i sur. 2007).

Uljna pogača lana zbog značajnog udjela proteina (25-40\%) predstavlja sirovinu koja pronalazi svoju primjenu i u tehnologiji životinjskih stanica (Gutiérrez i sur. 2010), bundeve (Peričin i sur. 2009), konoplje (Tang i sur. 2009) te pogače lana (Nwachukwu i Aluko 2018). Nadalje, ispitani su 
učinci različitih proteinskih hidrolizata biljnog podrijetla na proliferaciju životinjskih stanica te prinos i kvalitetu rekombinatnog proizvoda (Kim i Lee 2009; Babcock i sur. 2010; Spearman i sur. 2014). Međutim, mogući učinak proteinskog izolata i hidrolizata iz uljne pogače lana na proliferaciju i produktivnost industrijski važnih staničnih linija do sada nije temeljito istražen. Imajući u vidu dosad ispitana i dokazana svojstva proteinskih hidrolizata različitog biljnog podrijetla na rast i produktivnost stanica, cilj ovog rada je bio ispitati učinak proteinskog izolata iz uljne pogače lana na rast i produktivnost životinjskih CHO-E stanica, koje proizvode rekombinantni humani eritropoetin (rhEpo) te na rast humanih HEK-293T stanica. Izvorno navedene stanične linije spadaju u skupinu ekspresijskog sustava stanica sisavaca i preporučene su od vodećih regulatornih agencija (Food and Drug Administration (FDA) i European Medicines Agency (EMA)) za proizvodnju rekombinantnih proteina i retrovirusa u biofarmaceutskoj industriji.

\section{Materijali i metode}

\section{Priprava proteinskog izolata iz uljne pogače lana}

Pri pripremi proteinskog izolata korištena je odmašćena uljna pogača lana dobivena od lokalnog proizvođača (OPG Janković, Zagreb, Hrvatska). Postupak izolacije proveden je po protokolu Udenigwe i sur. (2009) s određenim modifikacijama. 75 g odmašćene pogače lana otopljeno je u $1500 \mathrm{~mL}$ deionizirane vode $(5 \% \mathrm{w} / \mathrm{v})$ uz miješanje na magnetskoj miješalici. Smjesa je zatim zagrijana na $37^{\circ} \mathrm{C}$, pH vrijednost podešena na 5,0 dodatkom $1 \mathrm{M} \mathrm{HCl}$, nakon čega je dodan enzim celulaza (Sigma, SAD) $(1 \% \mathrm{w} / \mathrm{w})$. Nakon 4 sata miješanja, smjesa je ohlađena na $4{ }^{\circ} \mathrm{C}$, a pH vrijednost podešena na 10,0 dodatkom $1 \mathrm{M}$ $\mathrm{NaOH}$. Zatim je smjesa centrifugirana pri $4000 \mathrm{~g}$, tijekom 30 minuta na $20^{\circ} \mathrm{C}$. Supernatantu je podešena $\mathrm{pH}$ vrijednosti na 4,2 dodatkom $1 \mathrm{M} \mathrm{HCl}$ što dovodi do taloženja proteina. Slijedi još jedan postupak centrifugiranja pri $4000 \mathrm{~g}$ tijekom $10 \mathrm{~min}$ na $20{ }^{\circ} \mathrm{C}$. Dobiveni talog je homogeniziran deioniziranom vodom te mu je $\mathrm{pH}$ vrijednost podešena na 7,0 dodatkom $1 \mathrm{M} \mathrm{NaOH}$. Tako pripremljena suspenzija je sušena pri $45^{\circ} \mathrm{C}$ preko noći. Nakon što je osušen, proteinski izolat je usitnjen u tarioniku, izvagan i spremljen na $4{ }^{\circ} \mathrm{C}$ do korištenja. Pripremljeni proteinski izolat je otopljen u deioniziranoj vodi, steriliziran kroz filter $(0,22 \mu \mathrm{m})$ (Corning, SAD), a sadržaj proteina određen je metodom po Lowry-u (Lowry i sur. 1951).

\section{Učinci proteinskog izolata iz pogače lana na rast staničnih linija CHO-E i HEK-293T}

Korištena stanična linija CHO-E razvijena je u Pliva d.d. (Hrvatska), a HEK-293T donacija je Animal Cell Technology Unit iz instituta iBET (Portugal). Nakon što su stanice uzgajane u T-boci postigle konfluentnost, nacijepljene su u ploče s 24 jažice u početnoj koncentraciji od $2 \times 10^{4} \mathrm{st} \mathrm{mL}^{-1}$ u $0,5 \mathrm{~mL}$ DMEM medija za uzgoj (Sigma, SAD) s dodatkom 5\% fetalnog goveđeg seruma (FBS, Gibco, SAD) i 1\% antibiotika (Gibco, SAD). Stanice su ostavljene tijekom $24 \mathrm{~h}$ da se prihvate za dno jažica. Nakon tog vremena, iz jažica je uklonjen medij i dodan je novi DMEM medij s različitim koncentracijama proteinskog izolata lana i seruma. Za HEK-293T i CHO-E stanične linije pripravljen je DMEM mediji koji sadrže 5\% seruma te je u sve medije dodan proteinski izolat iz pogače lana u koncentracijama od $0,1-4 \mathrm{~g} \mathrm{~L}^{-1}$. Kao kontrola služio je DMEM medij s dodatkom 5\% seruma, a bez dodatka izolata proteina. $U$ pripremljenim medijima određena je koncentracija proteina metodom po Lowry-u, a profil proteina određen je SDS-PAGE elektroforezom po Laemmli-ju (Laemmli 1970).

\section{Određivanje broja stanica metodom tripan-plavo}

Dinamika rasta stanica praćena je tijekom šest dana brojanjem u Neubauerovoj komorici uz dodatak boje tripan-plavo. Hranjivi medij je uklonjen iz jažica te je dodano $0,1 \mathrm{~mL}$ tripsina. Nakon odvajanja stanica dodano je 0,2 mL DMEM medija sa serumom kako bi se spriječilo daljnje djelovanje tripsina na stanice. Stanice su resuspendirane te je $10 \mu \mathrm{L}$ suspenzije stanica pomiješano s $10 \mu \mathrm{L} 0,4 \%$ boje tripan-plavo (Sigma, SAD). Od tako pripremljenog uzorka alikvotirano je $10 \mu \mathrm{L}$ koji su nanešeni u Neubauerovu komoricu. Pod mikroskopom je određen broj živih stanica brojanjem u četiri središnja kvadrata komorice dok se mrtve stanice zbog oštećene membrane boje plavo.

\section{Određivanje koncentracije specifičnog rekombinantnog proteina}

Koncentracija rekombinantnog humanog eritropoetina kojeg proizvodi stanična linija CHO-E određena je komercijalnim imunoenzimskim ELISA testom (Sigma-Aldrich, SAD) po protokolu proizvođača.

\section{Rezultati i rasprava}

Nusproizvodi prehrambene industrije, koji između ostalih komponenti sadrže i proteine, predstavljaju potencijalnu sirovinu s mogućom primjenom za uzgoj kultura životinjskih stanica. Prema dostupnoj literaturi učinak proteinskog izolata $i$ hidrolizata iz uljne pogače lana na rast $i$ produktivnost životinjskih stanica do sada nije bio ispitan. Stoga je cilj ovog istraživanja bio odrediti učinak proteinskog izolata, međuproizvoda u procesu priprave hidrolizata, na rast i produktivnost stanične linije CHO-E. Također, ispitan je i učinak dodatka proteinskog izolata iz pogače lana na rast HEK-293T stanice. Rast CHO-E i HEK-293T stanica praćen je tijekom 144 sata, pri čemu su obje stanične linije nakon 96 sati ušle u stacionarnu fazu rasta nakon čega je analiziran učinak izolata.

Koncentracija proteina $\mathrm{u}$ pripravljenom proteinskom izolatu iznosila je 45,6 $\mathrm{g} \mathrm{L}^{-1}$, odnosno udio proteina u izolatu s obzirom na početnu masu pogače lana iznosio je 43,7\% (w/w). Uzevši u obzir početni udio proteina u pogači lana, Mueller i sur. (2010) i Gutiérrez i sur. (2010) su u svojim ispitivanjima postigli udio između 50-65\%. Razlike u dobivenim udjelima proteina mogu se pripisati različitim uvjetima izolacije kao i različitoj početnoj sirovini. Za potrebe istraživanja učinaka proteinskog izolata na rast staničnih linija HEK-293T i CHO-E pripremljen je DMEM hranjivi mediji, s različitim koncentracijama seruma i proteinskog izolata iz uljne pogače lana te je određen njihov sadržaj proteina i proteinski profil SDS-PAGE elektroforezom (Slika 1 a. ib.). Na Slici 1 a. vrpce veličine 58-72 kDa predstavljaju proteine seruma, dok vrpce veličine $22-25 \mathrm{kDa}$ pripadaju proteinima izolata. Vidljivo je kako se povećanjem koncentracija proteinskog izolata dodanih u hranjivi medij povećava i intenzitet vrpci veličine $22-25 \mathrm{kDa}$ (Slika 1 a.) kao i ukupna koncentracij proteina u pripravljenim medijima (Slika 1 b.). 


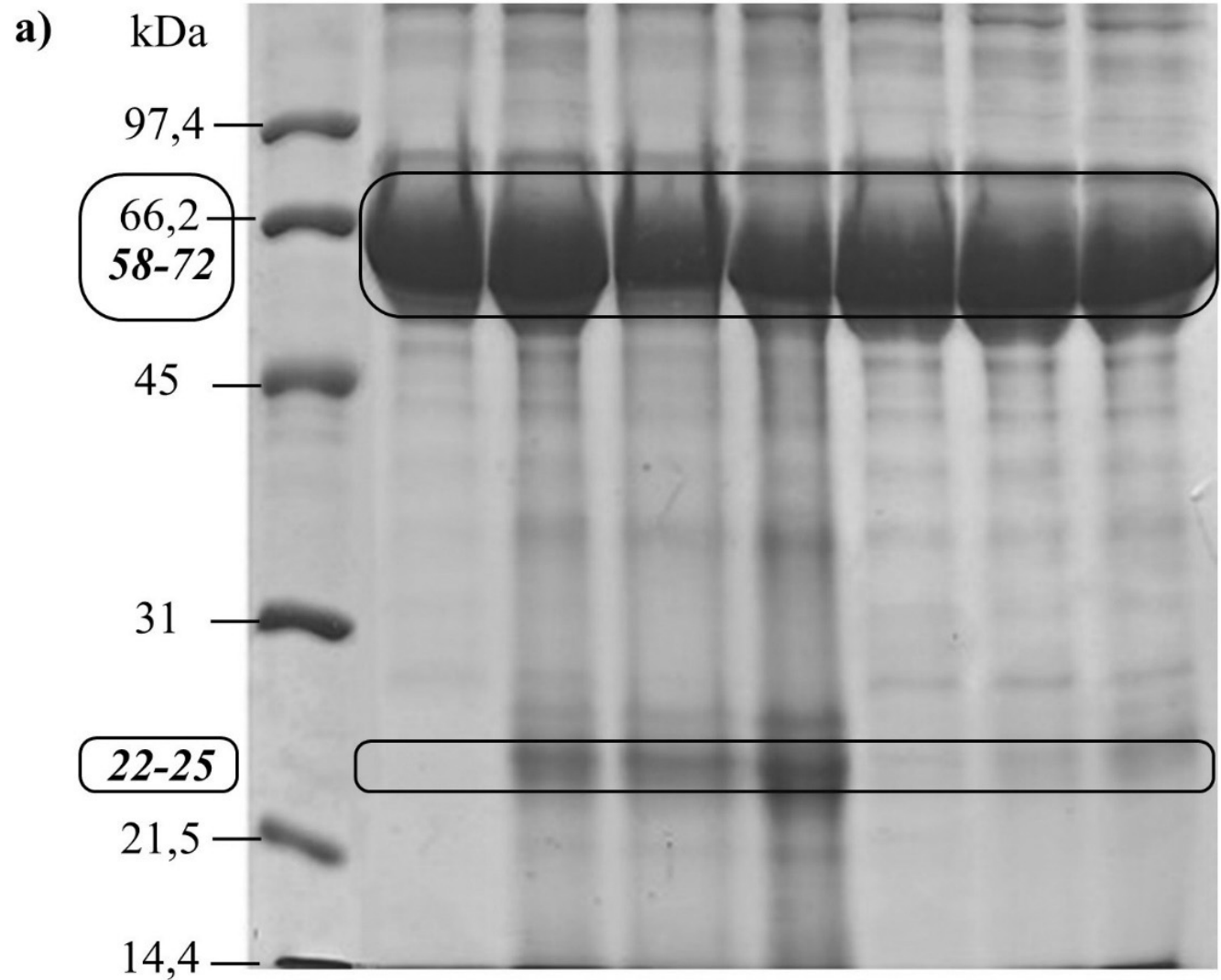

$\begin{array}{llllllll}\mathrm{S} & 1 & 2 & 3 & 4 & 5 & 6 & 7\end{array}$

b)

\begin{tabular}{|c|l|l|l|l|l|l|l|}
\hline $\begin{array}{c}\text { Ukupna } \\
\text { koncentracija } \\
\text { proteina }\left(\mathrm{g} \mathrm{L}^{-1}\right) \\
\text { Total protein } \\
\text { concentration } \\
\left(\mathrm{g} \mathrm{L}^{-1}\right)\end{array}$ & 3,3 & 4,2 & 4,8 & 5,9 & 3,4 & 3,8 & 4,0 \\
\hline
\end{tabular}

Slika 1. a) SDS-PAGE-proteinski profil u uzorcima medija. S-standardi. Medij s 5\% seruma te 0, 1,2 i $4 \mathrm{~g} L^{-1}$ izolata pogače lana (1-4) i 0,1, 0,2 i 0,4 g L $\mathrm{L}^{-1}$ izolata pogače lana (5-7).

b) Ukupna koncentracija proteina u medijima nakon dodatka seruma i proteinskog izolata iz uljne pogače lana (1-7).

Figure 1. a) SDS-PAGE-protein profile in media samples. S-standards. Medium with 5\% serum and 0, 1,2 and $4 \mathrm{~g} L^{-1}$ of protein isolate from flaxseed oil cake (1-4) and 0.1, 0.2 and $0.4 \mathrm{~g} \mathrm{~L}^{-1}$ flaxseed oil cake protein isolate (5-7).

b) Total protein concentration in media after addition of serum and protein isolate from flaxseed oil cake (1-7).

Na krivulji rasta stanične linije HEK-293T (Slika 2 a.) može se uočiti da jedino dodatak proteinskog izolata uljne pogače lana od $0,1 \mathrm{~g} \mathrm{L^{-1 }} \mathrm{u}$ hranjivi medij ima blago pozitivan učinak na stanični rast s obzirom na kontrolu u eksponencionalnoj fazi rasta (96 h). To je vidljivo i iz Slike $2 \mathrm{~b}$. gdje stanice u mediju s dodatkom $0,1 \mathrm{~g} \mathrm{~L}^{-1}$ izolata imaju najveću specifičnu brzinu rasta $0,0418 \mathrm{~h}^{-1}$. Stanice uzgajane u hranjivom mediju u koji je dodano $1 \mathrm{~g} \mathrm{~L}^{-1}$ izolata ne pokazuju ni pozitivan ni negativan učinak na rast stanica, dok dodatak izolata u ostalim koncentracijama pokazuje inhibitorni učinak na rast. 
a)

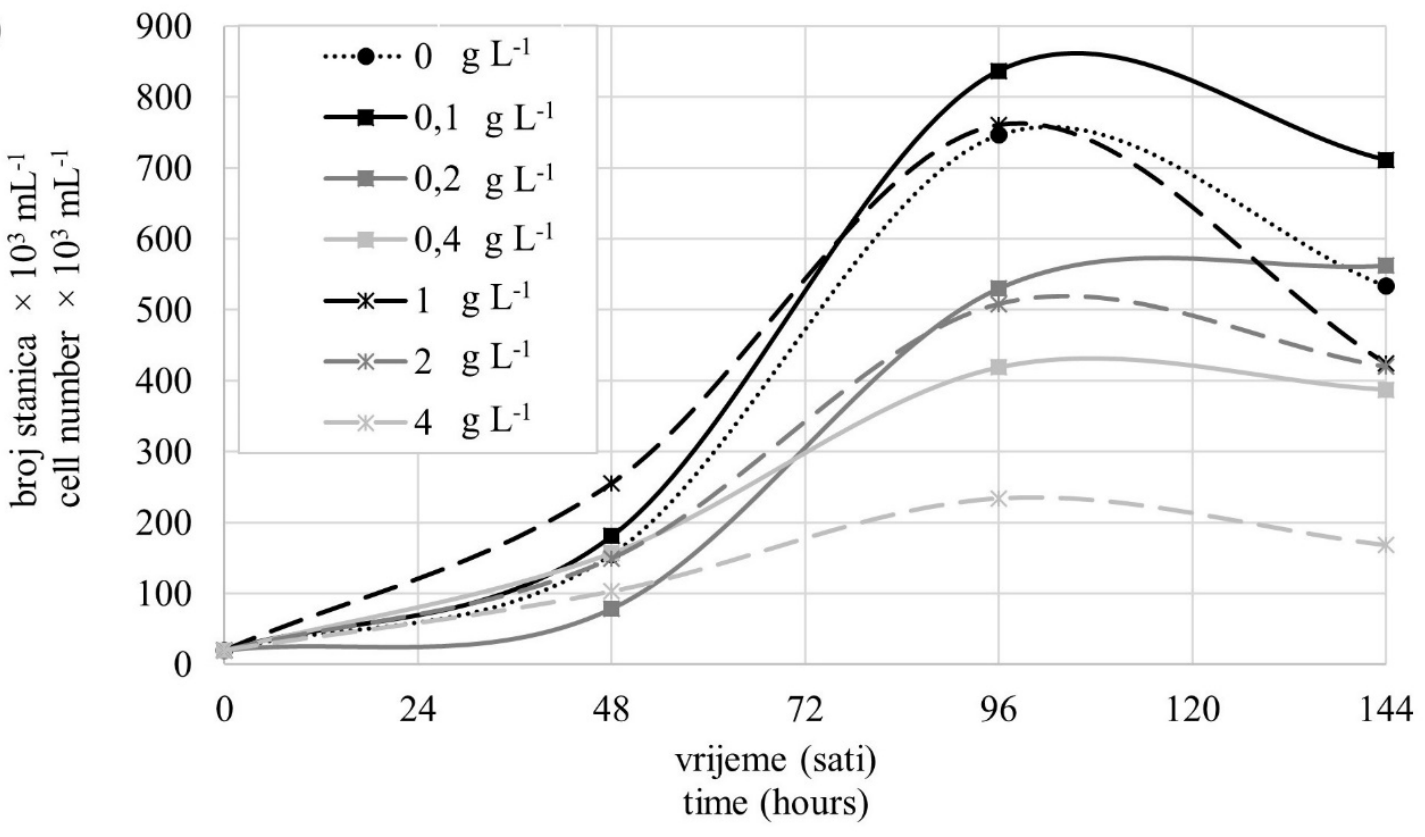

b)

\begin{tabular}{|c|c|}
\hline $\begin{array}{c}\text { Proteinski izolat iz pogače lana }\left(\mathrm{g} \mathrm{L}^{-1}\right) \\
\text { Flaxseed oil cake protein isolate }\left(\mathrm{g} \mathrm{L}^{-1}\right)\end{array}$ & $\begin{array}{c}\text { Specifična brzina rasta stanica }\left(\mathrm{h}^{-1}\right) \\
\text { Specific growth rate }\left(\mathrm{h}^{-1}\right)\end{array}$ \\
\hline 0 & 0,0403 \\
\hline 0,1 & 0,0418 \\
\hline 0,2 & 0,0371 \\
\hline 0,4 & 0,0336 \\
\hline 1 & 0,0406 \\
\hline 2 & 0,0359 \\
\hline 4 & 0,0266 \\
\hline
\end{tabular}

Slika 2. a) Krivulja rasta HEK-293T stanica pri različitim koncentracijama proteinskog izolata iz uljne pogače lana u mediju s 5\% seruma. Punom linijom označene su stanice uzgajane u mediju s dodatkom 0,1, 0,2 i 0,4 $\mathrm{g} \mathrm{L}^{-1}$ proteinskog izolata, a iscrtkanom linijom s dodatkom $10 x$ veće koncentracije. Kontrola je prikazana točkastom linijom.

b) Specifična brzina rasta HEK-293T stanica kultiviranih bez ili uz dodatak različitih koncentracija proteinskog izolata (0,1 - $4 \mathrm{~g}$ $\left.L^{-1}\right)$ u mediju s $5 \%$ seruma.

Figure 2. a) Growth curve of HEK-293T cells in culture medium supplemented with serum (5\%) and different concentrations of flaxseed protein isolate. Full line indicates cells grown in media supplemented with 0.1, 0.2, and $0.4 \mathrm{~g} \mathrm{~L}{ }^{-1}$ protein isolate, while media supplemented with 10x higher concentrations are marked with dashed line. Control is shown with dotted line.

b) Specific growth rate of HEK-293T cells cultured without or with addition of different concentrations of protein isolate (0.1 - $4 \mathrm{~g}$ $\left.L^{-1}\right)$ in medium with $5 \%$ serum.

Ispitivanje utjecaja proteinskog izolata uljne pogače lana na rast je provedeno i s CHO-E staničnom linijom pri čemu je praćen i učinak izolata na njihovu produktivnost s obzirom da se radi o staničnoj liniji koja proizvodi rekombinantni humani eritropoetin. Slično kao i kod HEK-293T stanica, CHO-E stanice uzgajane u mediju s dodatkom $0,1 \mathrm{~g} \mathrm{~L}^{-1}$ pokazuju blago stimulirajući učinak na rast stanica. No, za razliku od HEK-293T stanica kod kojih dodatak od $0,2 \mathrm{~g} \mathrm{~L}^{-1}$ izolata pokazuje negativan utjecaj na rast stanica, kod CHO-E stanične linije je pri toj koncentraciji zapažen najbolji rast stanica u odnosu na kontrolu, što je vidljivo i iz vrijednosti specifične brzine rasta (Slika 3 a. i b.). Slično kao i kod HEK-293T stanica, CHO-E stanice s dodatkom $1 \mathrm{~g} \mathrm{~L}^{-1}$ proteinskog izolata rastu kao i u kontrolnom mediju, dok dodatak ostalih koncentracija izolata u hranjivi medij dovodi do inhibicije rasta $\mathrm{CHO}-\mathrm{E}$ stanica. 
a)

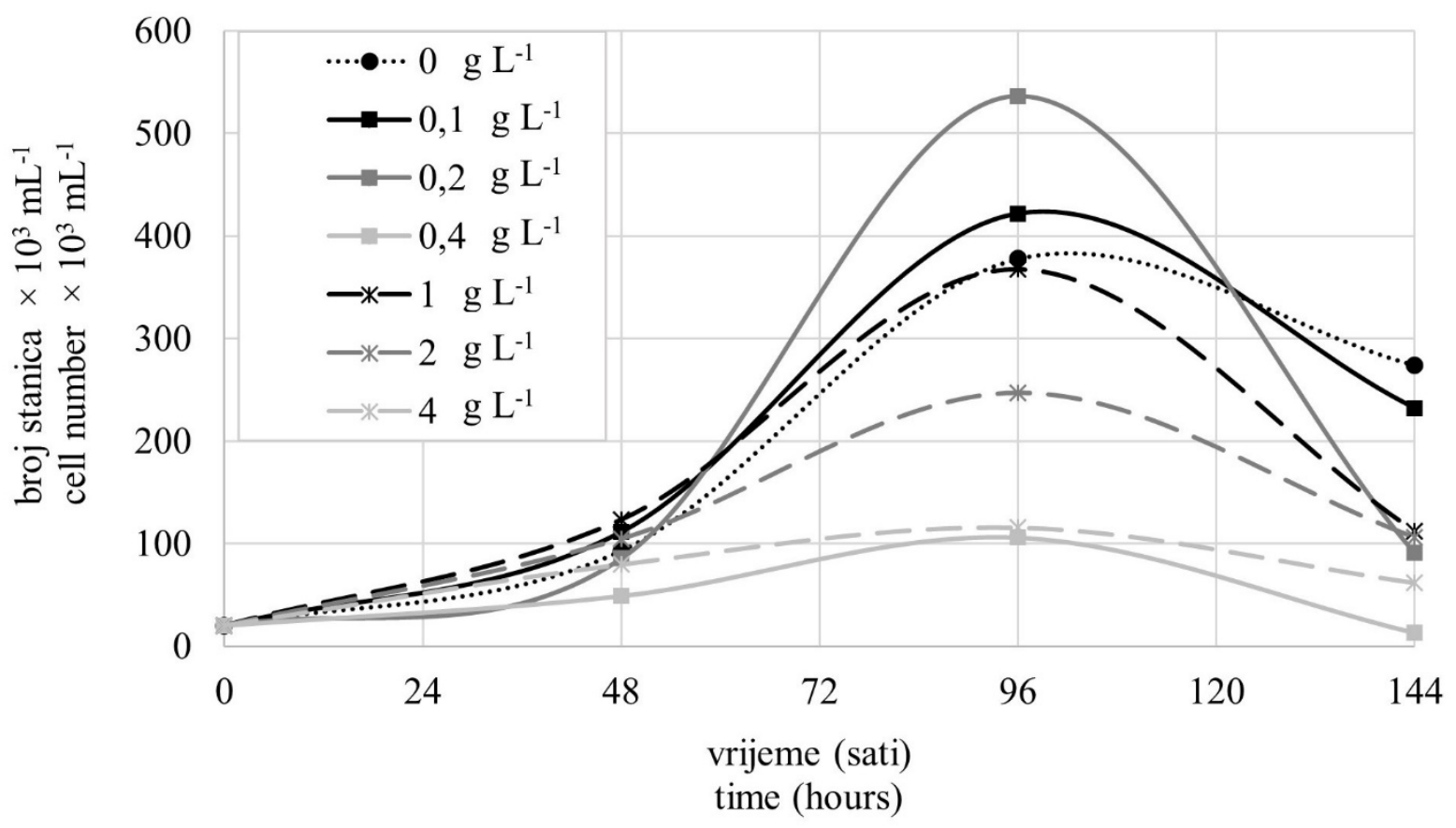

b)

\begin{tabular}{|c|c|}
\hline $\begin{array}{c}\text { Proteinski izolat iz pogače lana }\left(\mathrm{g} \mathrm{L}^{-1}\right) \\
\text { Flaxseed oil cake protein isolate }\left(\mathrm{g} \mathrm{L}^{-1}\right)\end{array}$ & $\begin{array}{c}\text { Specifična brzina rasta stanica }\left(\mathrm{h}^{-1}\right) \\
\text { Specific growth rate }\left(\mathrm{h}^{-1}\right)\end{array}$ \\
\hline 0 & 0,0320 \\
\hline 0,1 & 0,0331 \\
\hline 0,2 & 0,0365 \\
\hline 0,4 & 0,0192 \\
\hline 1 & 0,0311 \\
\hline 2 & 0,0273 \\
\hline 4 & 0,0198 \\
\hline
\end{tabular}

Slika 3. a) Krivulja rasta CHO-E stanica pri različitim koncentracijama proteinskog izolata iz uljne pogače lana u mediju s $5 \%$

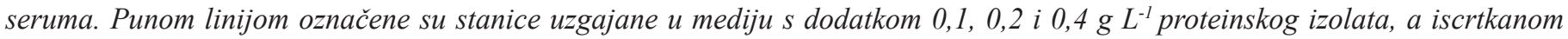
linijom s dodatkom $10 x$ veće koncentracije. Kontrola je prikazana točkastom linijom.

b) Specifična brzina rasta CHO-E stanica kultiviranih bez ili uz dodatak različitih koncentracija proteinskog izolata $\left(0,1-4 g L^{-1}\right)$ u mediju s $5 \%$ seruma.

Figure 3. a) Growth curve of CHO-E cells in culture medium supplemented with serum (5\%) and different concentrations of flaxseed protein isolate. Full line indicates cells grown in media supplemented with $0.1,0.2$, and $0.4 \mathrm{~g} \mathrm{~L}^{-1}$ protein isolate, while media supplemented with 10x higher concentrations are marked with dashed line. Control is shown with dotted line.

b) Specific growth rate of CHO-E cells cultured without or with addition of different concentrations of protein isolate (0.1 - $\left.4 \mathrm{~g} \mathrm{~L}^{-1}\right)$ in medium with $5 \%$ serum.

Također, određivana je i produktivnost CHO-E stanične linije u hranjivom mediju s 5\% seruma i različitim koncentracijama izolata nakon 96 sati uzgoja ELISA metodom. Dobiveni rezultati upućuju da najveću produktivnost u odnosu na kontrolu pokazuju stanice uzgajane u mediju s dodatkom $0,1 \mathrm{~g} \mathrm{~L}^{-1}$ i $0,2 \mathrm{~g} \mathrm{~L}^{-1}$ izolata (Slika 4). Dobiveni rezultati produktivnosti su u korelaciji s rezultatima rasta stanica. Uočljivo je da proteinski izolat uljne pogače lana dodan $\mathrm{u}$ hranjivi medij u koncentracijama većim od $0,2 \mathrm{~g} \mathrm{~L}^{-1}$ ima isti ili slabiji učinak na rast i produktivnost ispitivanih staničnih linija u odnosu na kontrolu, tj. na stanice uzgajane u mediju s 5\% seruma bez dodatka izolata. Dobiveni rezultati mogli bi se objasniti činjenicom da proteinski izolati uljnih pogača posjeduju zadovoljavajuću količinu i povoljan sastav aminokiselina, no imaju ograničena bioaktivna svojstva. Kako bi se poboljšale biološke funkcije proteina iz uljnih pogača, potrebno je provesti hidrolizu proteinskih izolata (Teh i Bekhit 2015). 
Isto tako, moguće je da dodatak većih koncentracija izolata dovodi do toga da se u mediju akumuliraju proteini koje stanice ne mogu iskoristiti zbog velikih molekulskih masa $(>10 \mathrm{kDa})$ te dolazi do zasićenja i samim time inhibitornog učinka na stanični rast i produktivnost. Zbog navedenih razloga većina se istraživanja fokusira na ispitivanje peptida, koji su zbog svoje manje molekulske mase te bioaktivnih svojstava, dostupniji stanicama te također mogu djelovati kao stimulatori staničnih funkcija (Siemensma i sur. 2010).

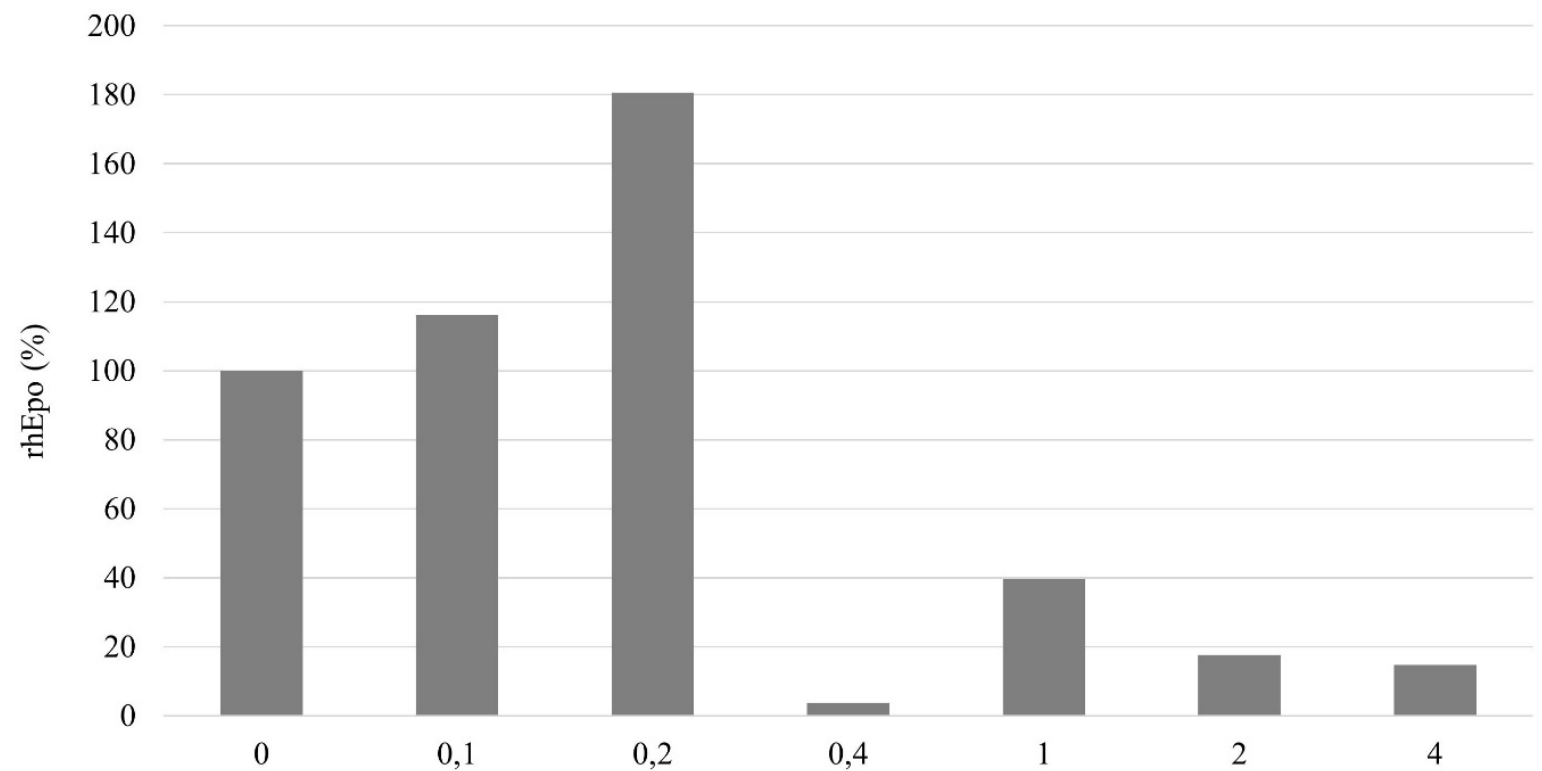

Koncentracija proteinskog izolata $\left(\mathrm{g} \mathrm{L}^{-1}\right)$ iz uljne pogače lana u mediju s dodatkom $5 \%$ seruma Concentration of flaxseed oil cake protein isolate $\left(\mathrm{g} \mathrm{L}^{-1}\right)$ in medium with $5 \% \mathrm{FBS}$

Slika 4. Relativna volumetrijska produktivnost CHO-E stanične linije.

Figure 4. Relative volumetric production of CHO-E cell line.

\section{Zaključci}

Korištenjem uljne pogače kao izvora proteina za primjenu u tehnologiji stanica stvara se dodana vrijednost otpadnom materijalu iz prehrambene industrije čime se poboljšava ekonomska isplativost i održivost proizvodnog procesa. Rezultati ovog istraživanja ukazuju da tijekom eksponencionalne faze rasta $(96 \mathrm{~h})$ dodatak proteinskog izolata uljne pogače lana u koncentracijama većim od $0,2 \mathrm{~g} \mathrm{~L}^{-1}$ za CHO-E stanice, odnosno $0,1 \mathrm{~g} \mathrm{~L}^{-1}$ za HEK-293T stanice, u hranjivi medij s 5\% seruma ne utječe pozitivno na rast stanica, nego štoviše ima inhibitorno djelovanje.

Blago stimulirajući učinak na rast imaju samo vrlo niske odnosno najmanja koncentracija izolata otopljenog u mediju s 5\% seruma. Kod CHO-E stanica pozitivan učinak dodanih niskih koncentracija izolata odražava se i na poboljšanu produktivnost tih proizvodnih stanica. Prikazani rezultati ukazuju na to da se blagi pozitivni učinak na stanični rast i produktivnost ne mogu pripisati isključivo proteinima izoliranim iz uljne pogače lana. Zapravo je vjerojatnije da oni djeluju inhibitorno, dok neki drugi biološki aktivni spojevi, među njima i peptidi, doprinose staničnoj proliferaciji, no tek pri sniženim koncentracijama ukupnih proteina. Budući da dosada, u dostupnoj znanstvenoj literaturi, nije istražen utjecaj proteinskog izolata uljne pogače lana na rast i produktivnost stanica, u nastavku istraživanja nužno je povezati i objasniti dobivene rezultate s temeljitijom analizom izolata. Rezultati prikazani u ovom radu ukazuju na to da proteinski izolati velikih molekulskih masa imaju ograničena bioaktivna svojstva te da ih stanice slabije iskorištavaju što dovodi do njihovog nakupljanja te negativnog utjecaja na stanični rast i produktivnost. Stoga će naša daljnja istraživanja biti usmjerena na ispitivanje učinka proteinskih hidrolizata uljne pogače lana na rast i produktivnost industrijski značajnih staničnih linija.

\section{Zahvala}

Zahvaljujemo Hrvatskoj zakladi za znanost za financiranju ovog istraživanja kroz projekt IP-2016-06-3848.

\section{Literatura}

Babcock J., Wilcox C., Huttinga H. (2010) Partial Replacement of Chemically Defined Media with Plant-Derived Protein Hydrolysates. Biopharm International, 23 (6) 36-41.

Chabanon G., Alves da Costa L., Farges B., Harscoat C., Chenu S., 
Goergen J. L., Chevalot I. (2008) Influence of the rapeseed protein hydrolysis process on CHO cell growth. Bioresource Technology, 99 (15) $7143-7151$.

Farges-Haddani B., Tessier B., Chenu S., Chevalot I., Harscoat C., Marc I., Marc A. (2006) Peptide fractions of rapeseed hydrolysates as an alternative to animal proteins in CHO cell culture media. Process Biochemistry, 41 (11) 2297-2304.

Gutiérrez C., Rubilar M., Jara C., Verdugo M., Sineiro J., Shene C. (2010) Flaxseed and flaxseed cake as a source of compounds for food industry. Journal of Soil Science and Plant Nutrition, 10 (4) 454-463.

Kim S. H., Lee G. M. (2009) Development of serum-free medium supplemented with hydrolysates for the production of therapeutic antibodies in $\mathrm{CHO}$ cell cultures using design of experiments. Applied Microbiology and Biotechnology, 83 (4) 639-648.

Laemmli U. K. (1970) Cleavage of structural proteins during the assembly of the head of bacteriophage T4. Nature 227 680-685.

Lowry O. H., Rosebrough N. J., Fair A. L., Randall R. J. (1951) Protein measurement with the Folin phenol reagent. Journal of Biological Chemistry, $193265-275$.

Moraes Â. M., Zucatelli Mendonça R., Torres Suazo C. A. (2008) Culture media for animal cells. U: Castilho L. R., Moraes Â. M., Augusto E. F. P., Butler M. (ured): Animal Cell Technology: From Biopharmaceuticals to Gene Therapy, str. 111-125. Taylor \& Francis Group, Abingdon, UK.

Mueller K., Eisner P., Yoshie-Stark Y., Nakada R., Kirchhoff E. (2010) Functional properties and chemical composition of fractionated brown and yellow linseed meal (Linum usitatissimum L.). Journal of Food Engineering, 98 (4) 453-460.

Nwachukwu I. D., Aluko R. E. (2018) Antioxidant Properties of Flaxseed Protein

Hydrolysates: Influence of Hydrolytic Enzyme Concentration and Peptide Size. JAOCS, Journal of the American Oil Chemists'Society, 95 (8) $1105-1118$.

Peričin D., Radulović-Popović L., Vaštag Ž., Madarev-Popović S., Trivić S. (2009) Enzymatic hydrolysis of protein isolate from hull-less pumpkin oil cake: Application of response surface methodology. Food Chemistry, 115 (2) 753-757.

Ramachandran S., Singh S. K., Larroche C., Soccol C. R., Pandey A. (2007) Oil cakes and their biotechnological applications - A review. Bioresource Technology, 98 (10) 2000-2009.

Siemensma A., Babcock J., Wilcox C., Huttinga H. (2010) Towards an Understanding of How Protein Hydrolysates Stimulate More Efficient Biosynthesis in Cultured Cells. U: Pasupuleti V. K., Demain A. L. (ured): Protein Hydrolysates in Biotechnology, str. 33-54. Springer, Dordrecht, Nizozemska.

Spearman M., Lodewyks C., Richmond M., Butler M. (2014) The bioactivity and fractionation of peptide hydrolysates in cultures of CHO cells. Biotechnology Progress, 30 (3) 584-593.

Tang C. H., Wang X. S., Yang X. Q. (2009) Enzymatic hydrolysis of hemp (Cannabis sativa L.) protein isolate by various proteases and antioxidant properties of the resulting hydrolysates. Food Chemistry, 114 (4) 1484-1490.

Teh S.-S., Bekhit A.E.-D.A. (2015) Utilization of Oilseed Cakes for Human Nutrition and Health Benefits. U: Hakeem K. R., Jawaid M., Alothman O. Y. (ed): Agricultural Biomass Based Potential Materials, str. 191-229. Springer, Cham, Švicarska

Udenigwe C. C., Lin Y. S., Hou W. C., Aluko R. E. (2009) Kinetics of the inhibition of renin and angiotensin I-converting enzyme by flaxseed protein hydrolysate fractions. Journal of Functional Foods, 1 (2) 199-207. 